\title{
Genetic Characterization and Sequence Variations in 12S rRNA of Mitochondrial Gene in Three Indian Civets (Viverridae) Species: Implication in Wildlife Forensics
}

\author{
Joshi BD, Singh SK and Goyal SP*
}

Wildlife Forensics and Conservation Genetics Cell, Wildlife Institute of India, Uttarakhand, India

${ }^{*}$ Corresponding author: Goyal SP, Wildlife Forensics and Conservation Genetics Cell, Wildlife Institute of India, Dehradun, Uttarakhand, India, E-mail: goyalsp@wii.gov.in

Citation: Joshi BD, Singh SK, Goyal SP (2017) Genetic Characterization and Sequence Variations in $12 \mathrm{~S}$ rRNA of Mitochondrial Gene in Three Indian Civets (Viverridae) Species: Implication in Wildlife Forensics. J Forensic Sci Criminol 5(1): 103. doi: 10.15744/2348-9804.5.103

Received Date: October 14, 2016 Accepted Date: February 27, 2017 Published Date: February 28, 2017

\begin{abstract}
Comparative genomics of $12 \mathrm{~S}$ and $16 \mathrm{~S}$ rRNAs, cytochrome $\mathrm{b}$ (Cyt b) and the control region (CR) of mtDNA genome are commonly used in phylogenetics and wildlife forensics. We document the genetic characteristics and sequence variations of $12 \mathrm{~S}$ rRNA (384 bp) in Indian civets, viz., the common palm civet (Paradoxurus hermaphroditus) ( $\mathrm{n}=9$ ), small Indian civet (Viverricula indica) ( $\mathrm{n}=7$ ) and Himalayan palm civet (Paguma larvata) $(\mathrm{n}=5)$. The nucleotide compositions vary from $17.6 \%$ to $36.3 \%$, and found one to two haplotypes in all three civet species. Observed sequence divergence was 0.001 to 0.002 and 0.057 to 0.110 within and between species respectively. The nucleotide diversity was 0.00102 to 0.00184 . Tajima's $\mathrm{D}$ value was negative (-0.097256 to -1.36240$)$ but statistically non-significant in all three species. Based on genetic characteristics, we discuss the use of observed forensically informative nucleotide sequencing (FINS) and topology in species identification for forensic purposes among these three civet species.
\end{abstract}

Keywords: Forensic; FINS; Civet; Species identification; Phylogenetic

\section{Introduction}

Family Viverridae (Order: Carnivora; Suborder: Feliformia) are cat - like animals and consists of 18 genera and 34 species [1]. These species display greater ecological diversification regarding trophic specialization and substrate use than any other family of carnivore [2]. Therefore, they are considered as an important keystone species because of their position in the food chain as they feed on a variety of invertebrates, small vertebrates, and plant part [2-5].

Although viverrid species have a wide distribution across the Old World tropics, the basic biology/ecology of most of the species has so far not been studied except few studies on phylogenetics and biogeography [6,7]. Whatever is known has been learned mostly from limited field observations and captive studies, except for a few quantitative ecological studies that have been undertaken on Asian civets $[3,4,8,9]$. Among the species of the family Viverridae found in India: the common palm civet (Paradoxurus hermaphroditus), commonly called the toddy cat is distributed throughout the India including the other regions of Asia [10]. Small Indian civet (Viverricula indica) is a tawny gray or grayish-brown viverrid found in forests and in hilly areas covered with scrub and tall grasses where there is sufficient cover to provide refuge during the day time [11]. The masked palm civet or Himalayan palm civet, (Paguma larvata) is a medium-sized mammal, and it is native to a regions extending throughout the Himalayas and from Assam southward to Myanmar, Thailand, Laos, Vietnam, the Malay Peninsula Borneo, Sumatra, and the Andaman Islands [12-14].

Species of Viverrids are being threatened by habitat degradation, various anthropogenic activities and poaching. Civets are being hunted for meat, civet oil, fur and body parts, which are sometimes used in folk medicine in Southeast Asia [15-19]. The extent of the trade is such that the collection of civet oil, from the anal glands, has impacted the conservation of at least three genera (Civettictis, Viverra, and Viverricula) [20]. Because hunting is known to reduce the size of a population and may affect the demography by altering age and sex structures and disrupt social systems [21-26]. Thus may have an impact on in situ conservation in general $[21,22]$. Therefore, such studies have identified a need for monitoring and understanding genetic changes in populations that are vulnerable to hunting as well as other anthropogenic drivers. Moreover, information on genetic characterization has also widely been used in wildlife forensic for identifying species because most of the parts traded are difficult to identify based on morphological characters. 
In the absence of ecological/biological information, understanding the genetic variation/divergence among species/populations that have provided insight into the trend of evolutionary pattern/population demography. Such information is always useful for developing effective management measures for conserving species in changing land use pattern [27-29]. Different genes of the mitochondrial genome (12S \& $16 \mathrm{~S}$ rRNAs, Cyt b, and CR) have been used in characterizing genetic diversity and subsequent use in wildlife forensics. However, for using, fast-evolving genetic markers such as Cyt b, CR, and cytochrome Oxidase Subunit I (COI), information on DNA sequence variation across intra and inter-species are needed to decide threshold level as a percent similarity for species identification [30]. In the absence of such information, use of highly conserved genes (12S \&16S rRNAs) across species is much safer to avoid any false identification as suggested for use in wildlife forensics [31]. Because of highly conserved genes of mtDNA genome, molecular identification of species based on $12 \mathrm{~S}$ and $16 \mathrm{~S}$ rRNAs genes have widely been used in phylogenetic and species identification and for the analysis of degraded biological materials that are often found in wildlife offense cases [3236]. Therefore we describe genetic characteristics and forensically informative nucleotide sequencing (FINS) in $12 \mathrm{~S}$ rRNA in these three civet species in India for dealing with wildlife offenses.

\section{Materials and Methods}

Skin samples of the common palm civet $(n=9)$, small Indian civet $(n=7)$ and Himalayan palm civet $(n=5)$ collected from different parts of India (during 2007-2011) were provided by the Wildlife Forensics Cell, Wildlife Institute of India, Dehradun, India in 2011 (Table 1). Genomic DNA was obtained from the skins and purified using a QIAamp Blood and Tissue Kit according to the manufacturer's protocol (Qiagen, Germany). A fragment of the DNA (384 bp) was amplified using the mitochondrial 12S rRNA primers L1091 (5'-AAA AAG CTT CAA ACT GGG ATT AGA TAC CCC ACT AT-3') and H1478 (5'-TGA CTG CAG AGG GTG ACG GGC GGT GTG T-3') [37]. Polymerase chain reaction (PCR) was carried with the $10 \mu$ of the PCR master mix contained $1 \times$ PCR buffer, $2 \mathrm{mM} \mathrm{MgCl}, 200 \mu \mathrm{M}$ dNTP, $0.4 \mu \mathrm{M}$ of each primer, $0.5 \mathrm{U}$ Taq gold polymerase (MBI Fermantas) and 40 ng of genomic DNA. The PCR thermal cycling parameters included initial denaturation at $94^{\circ} \mathrm{C}$ for 2 minutes, followed by 45 cycles of denaturation at $94^{\circ} \mathrm{C}$ for 45 seconds, annealing at $55^{\circ} \mathrm{C}$ for 1 minute and extension at $72^{\circ} \mathrm{C}$ for 1 minute, with a final extension for 20 minutes at $72^{\circ} \mathrm{C}$. The amplification was checked by loading $4 \mu \mathrm{l}$ of the reaction mixture on a $2 \%(\mathrm{w} / \mathrm{v})$ agarose gel. The amplified PCR products were subjected to ExoSAP (Exonuclease I-Shrimp Alkaline Phosphatase). Cycle sequencing PCR was performed for these purified PCR products using the respective forward and reverse primers with a master mixture of the composition suggested by Applied Biosystems. These products were then subjected to DNA sequencing in an ABI 3130 Genetic Analyzer.

\begin{tabular}{|c|c|c|c|c|}
\hline & T & C & A & G \\
\hline Common palm civet $(\mathbf{n}=\mathbf{9})$ & 23.7 & 22.1 & 36.3 & 17.8 \\
\hline Small Indian civet $(\mathbf{n}=\mathbf{7})$ & 22.5 & 23.9 & 35.5 & 18.1 \\
\hline Himalayan palm civet $(\mathbf{n}=\mathbf{5})$ & 22.9 & 22.7 & 36.1 & 18.3 \\
\hline
\end{tabular}

$\mathrm{n}=$ number of individuals

Table 1: Nucleotide composition in civet species

\section{Data analysis}

All sequences were cleaned, and examined for quality of data and edited using Sequencher 4.7 (Gene Codes, USA) using the forward and reverse primers. We used $384 \mathrm{bp}$ of the consensus sequence for ClustalW multiple alignments (CMA) in BioEdit v. 7.0.9.0 for further analysis [38]. The fixed-state FINS (only those nucleotides were noted which varied at single positions in all three species) was identified through manual visualization using the software BioEdit and MEGA v.6 and, nucleotide positions were provided based on the complete mitochondrial genome (GenBank no. CFU9663) of dog (Canis familiaris) [38-39]. The each peak was checked on Sequencher 4.7 to avoid any ambiguity to consider a mutation and only sharp peaks were considered (Figure 1). All generated sequences of $12 \mathrm{~S}$ rRNA in the present study were submitted to National Center for Biotechnology Information (NCBI; Accession Nos HQ634947-HQ634968). The nucleotide composition and sequence divergence were calculated using Kimura's two-parameter (K2P) in the MEGA v. 6. The genetic diversity indices and Tajima's test were assessed using DnaSP v. 5.10 to infer the demographic history [40]. The phylogenetic relationships with other groups such as the families Herpestidae, Mustelidae, and Felidae were also analyzed. Phylogenetic trees (gene tree) were constructed using different statistical methods, e.g., neighbour-joining (NJ), maximum likelihood (ML), and maximum parsimony (MP) using the bootstrap value of 1000 irritations implemented in the MEGA v. 6 [39]. The best-fit model for nucleotide substitution was tested for a hierarchical likelihood ratio using log-likelihood scores and applied in jModeltest v. 1.0 [41]. We use Hasegawa-Kishino-Yano + Gama nucleotide substation model $(\mathrm{HKY}+\mathrm{G})$ to construct the tree. Also, Bayesian inference (BI) phylogenetic tree was constructed using the BEAST v. 2 [42].

\section{Results}

The average nucleotide composition of the three viverrid species was T, 26.7\%; C, 24.5\%; A, 32.5\%; G, 15.5\% (Table 1). In all civet species, the A-T content (59.2\%) was greater than that of G-C (40\%). Fixed-state FINS were identified specifically for the family and species level, and these nucleotides were found at the positions of 535 and 545 (Table 2) according to complete genome of the dog and peaks were unambiguous (Figure 1). 


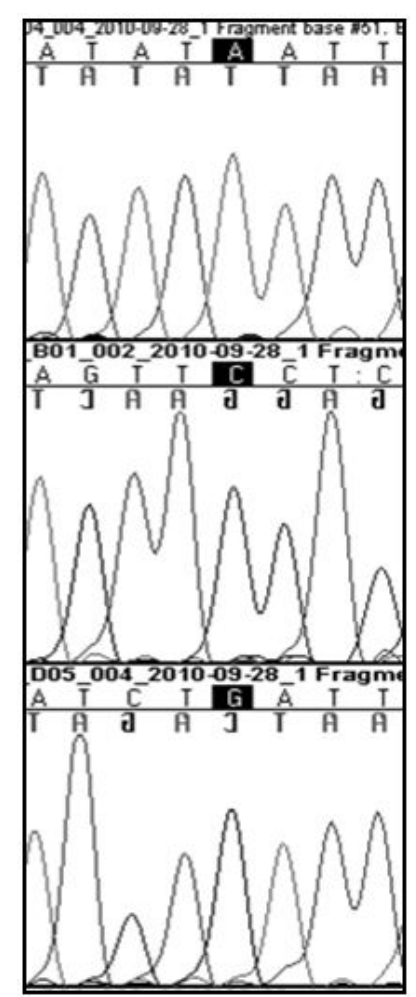

Figure 1: Observed peaks of FINS for the each civets species highlighted in black

\begin{tabular}{|c|c|c|}
\hline & \multicolumn{2}{|c|}{ Observed fixed-state nucleotide } \\
\hline Family/species & Species level & Family level \\
\hline & 5 & 5 \\
& 3 & 4 \\
\hline Viverridae & 5 & 5 \\
\hline P. hermaphroditus & $\mathrm{A}$ & $\mathrm{T}$ \\
\hline V. indica & $\mathrm{C}$ & $\mathrm{T}$ \\
\hline P. larvata & $\mathrm{G}$ & $\mathrm{T}$ \\
\hline Herpestidae & & $\mathrm{C}$ \\
\hline Mustelidae/ & & $\mathrm{A}$ \\
Felidae/ Canidae & & \\
\hline
\end{tabular}

Table 2: Family- and species-specific nucleotide positions in the 12S rRNA gene of mtDNA in three civet species and four other carnivore groups

The sequence divergence of $12 \mathrm{~S}$ rRNA among all the civet species was from 0.057 to 0.110 . The maximum divergence of 0.110 , was between the common palm civet and, small Indian civet whereas 0.086 between the small Indian civet and the Himalayan palm civet. The least divergence of 0.057 was between the common palm civet and Himalayan palm civet (Table 3 ). The sequence divergence within Viverridae groups was 0.049 which was higher than the most of the mammal's groups such as Perissodactyl (0.034), Lagomorpha (0.045), Marsupial (0.044) and Proboscidea (0.006) (Table 4).

\begin{tabular}{|c|c|c|c|}
\hline & CPC & SIC & HPC \\
\hline CPC & & & \\
\hline SIC & 0.105 & & \\
\hline HPC & 0.057 & 0.086 & \\
\hline
\end{tabular}

Table 3: Sequence divergence of mitochondrial 12S rRNA among the civet species of India

The observed nucleotide diversity $(\pi)$ was $0.00102,0.00066$ and 0.00184 in the common palm civet, small Indian civet, and Himalayan palm civet, respectively (Table 5). Tajima's D is a statistic that is widely used in determining whether or not genes are evolved randomly (neutral evolution) or regions are under selection (non-neutral evolution) by using DNA polymorphisms within species. It is based on estimates of genetic variation that can be calculated from the number of segregation sites and the nucleotide diversity [43]. We observed negative values of Tajima's D in the common palm civet (-1.36240), small Indian civet (-1.00623) and Himalayan palm civet $(-0.97256)$, and these were not significant at the $\mathrm{P}<0.05$ level (Table 5). 


\begin{tabular}{|c|c|c|}
\hline S.no. & Group & $\begin{array}{c}\text { Divergence } \\
\text { within group }\end{array}$ \\
\hline $\mathbf{1}$ & Lagomorpha & 0.045 \\
\hline $\mathbf{2}$ & Cetartiodactyla & 0.046 \\
\hline $\mathbf{3}$ & Chiroptera & 0.057 \\
\hline $\mathbf{4}$ & Proboscidea & 0.006 \\
\hline $\mathbf{5}$ & Insectivora & 0.066 \\
\hline $\mathbf{6}$ & Perissodactyl & 0.034 \\
\hline $\mathbf{7}$ & Primates & 0.056 \\
\hline $\mathbf{8}$ & Carnivora & 0.039 \\
\hline $\mathbf{9}$ & Macroscelidia & 0.041 \\
\hline $\mathbf{1 0}$ & Rodentia & 0.074 \\
\hline $\mathbf{1 1}$ & Marsupial & 0.044 \\
\hline $\mathbf{1 2}$ & Monotremes & 0.027 \\
\hline $\mathbf{1 3}$ & Viverridae $^{*}$ & 0.049 \\
\hline
\end{tabular}

* Present study

Table 4: Reported sequence divergence of 12srRNA gene from mitochondrial DNA

in different groups of mammals in relation to Viverridae. (Source: Tondon (2007)

\begin{tabular}{|c|c|c|c|c|c|c|c|}
\hline Population & $\boldsymbol{N}$ & Nhap & NhI & NhII & $\boldsymbol{S}$ & $\boldsymbol{\pi}(\%)$ & Tajima's D \\
\hline PC & 9 & 2 & 1 & 1 & 2 & 0.00102 & -1.36240 \\
SIC & 7 & 1 & 1 & - & 1 & 0.00066 & -1.00623 \\
HPC & 5 & 2 & 1 & 1 & 2 & 0.00184 & -0.97256 \\
\hline
\end{tabular}

$N$, number of individuals; Nhap, number of haplotypes; NhI, number of haplotype $1 ;$ NhII, number of haplotype II; $S$, number of variable sites; $\pi$, nucleotide diversity; $\mathrm{p}>0.10$, not significant; PC, common palm civet; SIC, small Indian civet; HPC, Himalayan palm civet

Table 5: Observed mtDNA diversity based on $12 \mathrm{~S}$ rRNA in three civet species of India

All phylogenetic tree topology constructed using different statistical methods were identical and maximum likelihood tree of three civet species is shown in (Figure 2).

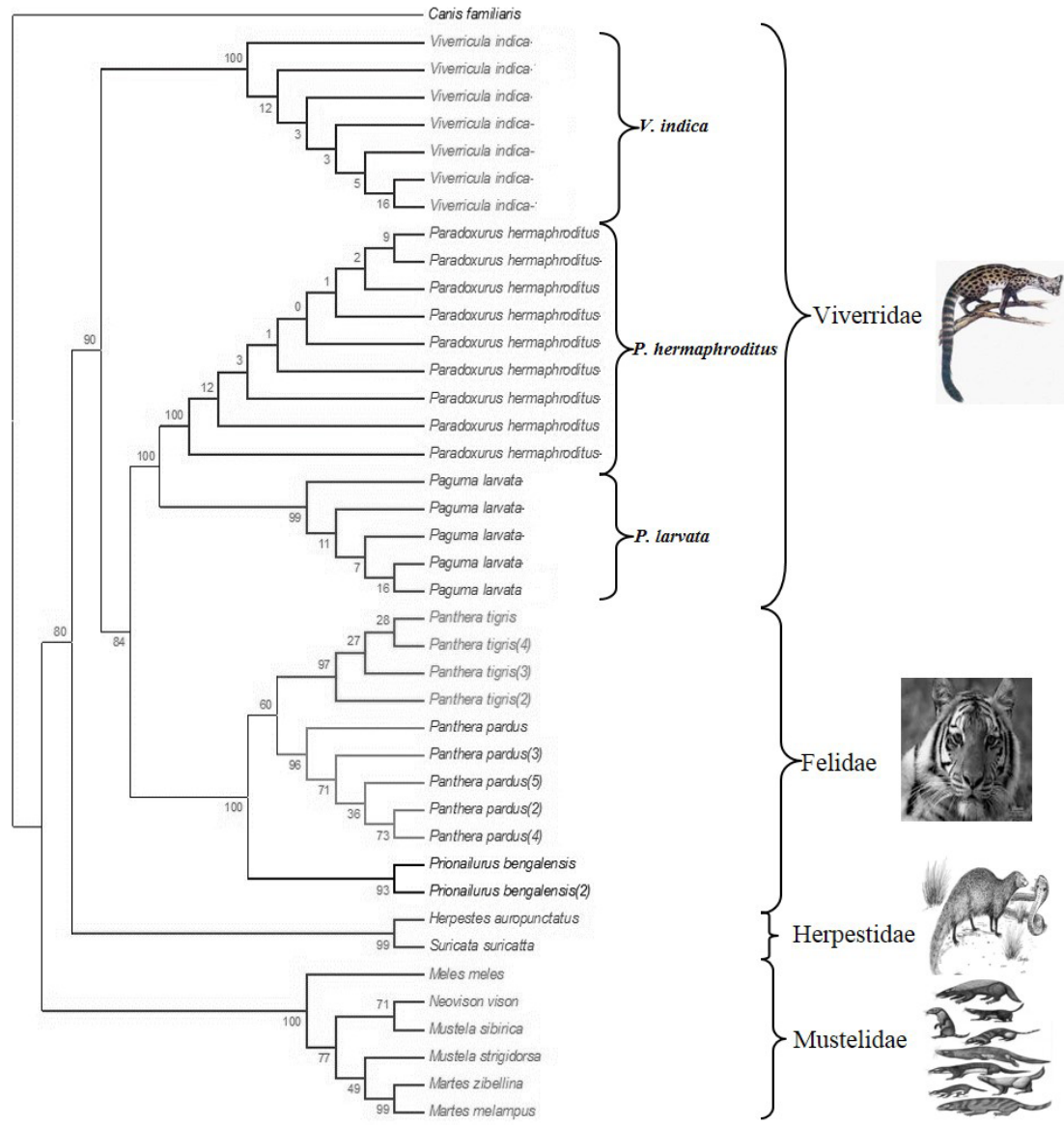

Figure 2: Phylogenetic analysis: ML tree constructed with a bootstrap value of 1000 with the families Felidae, Mustelidae, Herpestidae, and Viverridae, with Canis familiaris as the outgroup, using the MEGA v. 6 software package 


\section{Discussion}

In the present study, we describe the genetic characteristics and sequence variation in the 12S rRNA and their applicability in wildlife forensics and conservation. Observed fixed state FINS and genetic distance based topology of the mitochondrial genome of $12 \mathrm{~S}, 16 \mathrm{~S}$, and Cyt b have widely been used in identifying species as large data sets of different species are available at NCBI, USA $[44,45]$. Hence, these genes have been found suitable than the recently suggested cytochrome oxidase subunit I (COI) gene where available data sets of COI gene at present are not adequate for avoiding misidentification of species [30]. In contrast, use of the fast evolving genes such as Cyt b, CR, and COI of mtDNA genome required information on inter and intra-species variation to determine the threshold level of sequence similarity which varies 1.5-2.5\% for identification of species [30]. Comprehensive such database across the species range lack for South and Southeast Asian species. Moreover, the use of $12 \mathrm{~S}$ and $16 \mathrm{~S}$ rRNAs will have a very low possibility of having mutations at identified FINS due to highly conserved genes and therefore often been used across the taxa for molecular categorization [46]. Guha et al., (2006) reported that $16 \mathrm{~S}$ rRNA contains a larger number of conserved speciesspecific mutation sites than does the Cyt b gene [31]. Thus, it would be useful to identify such fixed-state FINS across taxa in these conserved genes ( $12 \mathrm{~S}$ and $16 \mathrm{~S}$ rRNAs), and the probability of misidentification of species will be very low as there is a high level of divergence between species and across families [47]. Our analysis of $12 \mathrm{~S}$ rRNA reveals the presence of two highly conserved fixedstate FINS at position 535 and 545, and these discriminate the three species of civet from each other as well as family Viverridae (Table 2). BLAST search at NCBI has been a common practice for identifying species where the chances of misidentification have been increased due to the absence of DNA profile database of species [48]. Therefore, use of FINS than the other approaches would minimize chances of false identification and have been suggested in wildlife forensics $[44,45,30]$.

The nucleotide diversity was found similar (0.001-0.006) to other mammals [49]. The Tajima's D values are negative in all three species in civets and were not statistically significant which may indicate a possible sudden population expansion [50].

Understanding and quantifying the level of sequence divergence across species is crucial in forensics, especially if the species are phylogenetically close [51,52]. The sequence divergence of $12 \mathrm{~S}$ rRNA for different groups of mammals is mostly between 0.027 and 0.074, except for Proboscidea [53]. The observed sequence divergence of 0.049 in the family Viverridae is within the range for most mammals (Table 4). Tondon, (2007) observed the greatest divergence (0.112) in the Monotremes and Proboscidea, whereas the least divergence (0.053) was in Carnivora and Perissodactyla [53].

Comparison of the civet sequences with those of three other carnivores groups, i.e. the families Herpestidae, Felidae, and Mustelidae, indicates that the divergence between the families Felidae and Mustelidae (0.131) is greater than that between the families Viverridae and Felidae (0.081) (Table 6). Our results are also in agreement with the findings of Veron and Heard, (2000) based on the Cyt b gene that the family Herpestidae is a sister group of both the families Viverridae and Felidae [54]. Besides, our finding also corroborates using $12 \mathrm{~S}$ rRNA, that the family Felidae is close to the family Viverridae compared with the families Mustelidae and Herpestidae, with a higher bootstrap supports (Figure 2). Two subfamilies of the family Viverridae (Viverrinae and Paradoxurinae) are paraphyletic [55,56]. Within the clade of family Viverridae, the Himalayan palm civet is much closer to the common palm civet, with a higher bootstrap value of 96 (Figure 2). Hence, the obtained higher bootstrap values at the nodes of each species indicate that the observed variability within the species is adequate to assign any sample with a high probability to a particular species. Therefore, suggested topology based species identification may also enhance correct identification of species using the 12S rRNA [57].

\begin{tabular}{|c|c|c|c|c|}
\hline & Viverridae & Herpestidae & Mustelidae & Felidae \\
\hline Viverridae & & & & \\
\hline Herpestidae & 0.111 & & & \\
\hline Mustelidae & 0.127 & 0.111 & & \\
\hline Felidae & 0.081 & 0.119 & 0.131 & 0.000 \\
\hline \multicolumn{7}{|c|}{$\begin{array}{l}\text { Table 6: Sequence divergence of mitochondrial 12S rRNA among } \\
\text { species of four families of carnivores }\end{array}$}
\end{tabular}

\section{Conclusion}

The sequence divergence and presence of species-specific FINS provided an understanding and the level of genetic divergence, phylogeny and dealing with wildlife offenses across various taxa. Besides, use of fixed-state FINS and topology with a node having high bootstrap values have been the powerful tool in classifying the samples of unknown species in wildlife forensics [57]. Therefore, we describe first time the use of sequence variation and genetic characteristic of conserved 12S rRNA of mtDNA genes in three Indian civet species of the family Viverridae. Observed haplotype and sequence variation of $12 \mathrm{~S}$ rRNA in these civet species are comparable with other species of mammals. We report fixed-state FINS for species and family-level identification. Civets being keystone species in the food chain, we suggest a need of maintaining diverse niches of these species for achieving long-term conservation under changing land use pattern. 


\section{Acknowledgements}

We extend our heartfelt thanks to Director and Dean, Wildlife Institute of India, Dehradun, India. We would like to extend our gratitude to our lab mates, who shared their personal experiences with us. We also thank the Dr. G. Veron to comments on the earlier versions of this manuscript. We also thank the technical staff of the Wildlife Forensics Cell for their support during the study.

\section{References}

1. Wozencraft WC (2005) Mammal Species of the World: A taxonomic and geographic reference. In: Wilson DE and Reeder DM, editors. Order Carnivora. Baltimore: Johns Hopkins University.

2. Eisenberg JE (1991) The mammalian relations: an analysis of trends in evolution, adaptation, and behavior. University of Chicago Press, Chicago, USA.

3. Joshi AR, Smith JLD, Cuthbert FJ (1995) Influence of food distribution and predation pressure on spacing behavior in palm civets. Journal of Mammal 76: 1205-12.

4. Rabinowitz AR (1991) Behaviour and movements of sympatric civet species in Huai Kha Khaeng wildlife sanctuary Thailand. J. Zool 223: 281-98.

5. Krishnakumar H, Balakrishnan M (2003) Feeding ecology of the common palm civet, Paradoxurus hermaphroditus (Pallas) in semi-urban habitats in Trivandrum, India. Small Carnivore Conservation. IUCN Publication 28: 10-11.

6. Patou ML, Chen J, Cosson L, Andersen DH, Cruaud C, Couloux A, Randi E, Zhang S, Veron G (2009) Low genetic diversity in the masked palm civet Paguma larvata (Viverridae). Journal of Zoology 278: 218-30.

7. Gaubert P, Cordeiro-Estrela P (2006) Phylogenetic systematics and tempo of evolution of the Viverrinae (Mammalia, Carnivora, Viverridae) within feliformians: Implications for faunal exchanges between Asia and Africa. Molecular Phylogenetics and Evolution 41: 266-78.

8. Jennings AP, Seymour AS, Dunstone N (2006) Ranging behaviour, spatial organization and activity of the Malay civet (Viverra tangalunga) on Buton Island, Sulawesi. Journal of Zoology 268: 63-71.

9. Jennings A P, Zubaid A, Veron G (2010) Ranging behaviour, activity, habitat use, and morphology of the Malay civet (Viverra tangalunga) on Peninsular Malaysia and comparison with studies on Borneo and Sulawesi. Mammalian Biology 75: 437-46.

10. Krishnakumar H, Balasubramanian NK, Balakrishnan M (2002) Sequential Pattern of Behavior in the Common Palm Civet, Paradoxurus hermaphroditus (Pallas). Intern J Comp Psychol 15: 303-11.

11. Lekagul B, McNeely JA (1977) Family Viverridae. In: Mammals of Thailand. Association for the conservation of wildlife. Lekagul B, Mcneely JA, editors. Kurusapha Press, Bangkok. 583- 585.

12. Ewer RF (1973) The Carnivores. Cornell Univ Press, Ithaca, New York.

13. Corbet GB, Hill JE (1992) The Mammals of the Indomalayan Region. Oxford University Press, Oxford.

14. Torii H (2009) Paguma larvata (Smith, 1827). The Wild Mammals of Japan. In: Ohdachi SD, Ishibashi Y, Iwasa MA, Saitoh T, editors. Shoukadoh, Kyoto 267268.

15. Myers P (2008) Viverridae. Animal Diversity Web., 2000, Retrieved December.

16. Schreiber A, Wirth R, Riffel M, Van-Rompaey H (1989) Weasels, civets, mongooses and their relatives: an action plan for conservation of mustelids and viverrids. IUCN/SSC, Gland, Switzerland, 1989.

17. Corlett RT (2007) The impact of hunting on mammalian fauna of tropical Asian forests. Biotropica 39: 292-303.

18. Shepherd CR (2008) Civets in trade in Medan, North Sumatra, Indonesia (1997-2001) with notes on legal protection. Small Carniv. Conserv 38: $34-6$.

19. Shepherd CR, Shepherd LA (2010) The trade in Viverridae and Prionodontidae in Peninsular Malaysia with notes on conservation and legislation. Small Carniv. Conserv 42: 27-9.

20. Balakrishnan M, Sreedevi MB (2007) Husbandry and management of the Small Indian Civet Viverricula indica (E. Geoffroy Saint-Hilaire, 1803) in Kerala, India. Small Carni. Conserv 36: 9-13.

21. Ginsberg JR, Milner-Gulland EJ (1994) Sex-biased harvesting and population-dynamics in ungulates-implications for conservation and sustainable use. Conserv. Biol 8: 157-66.

22. Milner JM, Bonenfant C, Mysterud A (2006) Temporal and spatial development of red deer harvesting in Europe: biological and cultural factors. J Appl Ecol 43: 721-34.

23. Swenson JE, Sandegren F, Oderberg AS, Bjarvall A, Franzen R et al. (1997) Infanticide caused by hunting of male bears. Nature, 386: 450-1.

24. Swenson JE, Dahle B, Sandegren F (2003) Implications of sexually selected infanticide for the hunting of large carnivores. In: Festa-Bianchet M, Apollonio M, editors. Animal Behaviour and Wildlife Conservation. Island Press Washington, DC, USA 171-89.

25. Proaktor G, Coulson T, Milner-Gulland EJ (2007) Evolutionary responses to harvesting in ungulates. J. Anim. Ecol 76: 669-78.

26. Law R (2007) Fisheries induced evolution: present status and future directions. Mar. Ecol. Prog. Ser 335: 271-7.

27. Avise JC (1996) The scope of conservation genetics. In: Avise JC, Hamrick JL, editors. Conservation Genetics. Case Histories from Nature, Chapman \& Hall, New York 1-9.

28. Lacy RC (1997) Importance of genetic variation to the viability of mammalian populations. J. Mammal, 1997, 78: 320-35.

29. Altizer S, Harvell D, Friedle E (2003) Rapid evolutionary dynamics and disease threats to biodiversity. Trends in Ecology and Evolution 18: 589-6.

30. Tobe SS, Kitchener AC, Linacre AMT (2010) Reconstructing Mammalian Phylogenies: A Detailed Comparison of the Cytochrome b and Cytochrome Oxidase Subunit I Mitochondrial Genes. PLoS ONE 5: e14156.

31. Guha S, Goyal SP, Kashyap VK (2006) Genomic variation in the mitochondrially encoded cytochrome b (MT-CYB) and 16S rRNA (MT-RNR2) genes: characterization of eight endangered Pecoran species. Anim. Genet 37: 262-65.

32. Douzery E, Catzeflis FM (1995) Molecular evolution of the mitochondrial 12S rRNA in Ungulata (Mammalia). Mol. Evol 41: 622-36. 
33. Lavergne A, Douzery E, Stichler T, Catzeflis FM, Springer MS (1996) Interordinal mammalian relationships: evidence for paenungulate monophyly is provided by complete mitochondrial 12S rRNA sequences. Mol. Phyl. Evol 6: 245-58.

34. Ledje C, Arnason U (1996) Phylogenetic relationships within Caniform carnivores based on analysis of the mitochondrial 12S rRNA gene. J Mol Evol 43: 641-9. 35. Guha S, Kashyap VK (2006) Molecular identification of lizard by RAPD \& FINS of $\quad$ mitochondrial 16s rRNA gene. Leg. Med 8: 5-10.

36. Guha S, Goyal SP, Kashyap VK (2006) Genomic variation in the mitochondrially encoded cytochrome b (MT-CYB) and 16S rRNA (MT-RNR2) genes: characterization of eight endangered Pecoran species. Anim. Genet 37: 262-65.

37. Kocher TD, Thomas WK, Meyer A, Edwards SV, Paabo S, et al. (1989) Dynamics of mitochondrial DNA evolution in animals: amplification and sequencing with conserved primers. Proc. Natl. Acad. Sci 86: 6196-200.

38. Hall TA (1999) Bioedit: a user friendly biological sequence alignment editor and analysis program for windows 95/98/NT. Nucl. Acid. Symp. Ser 41: 95-8.

39. Tamura K, Stecher G, Peterson D, Filipski A, Kumar S (2013) MEGA6: Molecular Evolutionary Genetics Analysis version 6.0. Mol Biol Evol 30: $2725-9$.

40. Librado P, Rozas J (2009) DnaSP v5: a software for comprehensive analysis of DNA polymorphism data. Bioinformat 25: 1451-2.

41. Posada D (2008) jModelTest: phylogenetic model averaging. Mol Biol Evol 25: 1253-6.

42. Bouckaert R, Heled J, Kühnert D, Vaughan TG, Wu CH (2014) BEAST2: A software platform for Bayesian evolutionary analysis. PLoS Comput. Biol 10: e1003537.

43. Tajima F (1989) Statistical methods to test for nucleotide mutation hypothesis by DNA polymorphism. Genet 123: 585-95.

44. Bartlett SE, Davidson WS (1992) FINS (forensically informative nucleotide sequencing): a procedure for identifying the animal origin of biological specimens. Biotechniques 12: 408-11.

45. Sahajpal V, Goyal SP (2009) Identification of a forensic case using microscopy and forensically informative nucleotide sequencing (FINS): A case study of small Indian civet (Viverricula indica). Sci Justice 50: 94-7.

46. Tserenbataa T, Ramey RR, Ryder OA, Quinn TW, Reading RP (2004) A population genetic comparison of argali sheep (Ovis ammon) in Mongolia using the ND5 gene of mitochondrial DNA; implications for conservation. Mol. Ecol 13: 1333-9.

47. Grosso AR, Bastos-Silveria C, Coelhom MM, Dias D (2006) Columba palumbus Cyt b-like Numt sequence: comparison with functional homologue and the use of universal primers. Folia. Zool 52: 31-144.

48. Elmeer K, Almalki A, Mohran KA, AL-Qahtani KN, Almarri M (2012) DNA barcoding of Oryx leucoryx using the mitochondrial cytochrome C oxidase gene. Genet. Mol. Res 11: 539-47.

49. Abhyankar A, Park HB, Tonolo G, Luthman H (2009) Comparative Sequence Analysis of the Non-Protein-Coding Mitochondrial DNA of Inbred Rat Strains. PLoS ONE 4: e8148.

50. Hudson RR, Kreitman M, Aguade M (1987) A test of neutral molecular evolution based on nucleotide data. Genet 116: 153-9.

51. Ward RD, Zemlak TS, Innes BH, Last PR, Hebert PDN (1847) DNA barcoding Australia’s fish species. Philos Trans R Soc Lond B Biol Sci 360: 1847-57.

52. Zaidi F, Wei Sj, Shi M, Chen Xx (2011) Utility of multigene loci for forensic species diagnosis of blowflies. Journal of insect science 11: 59.

53. Tondon M (2007) Genomic polymorphism and characterization of population: Special emphasis on endangered Wildlife University of Jadavpur (Ph.D. thesis), Kolkata, India.

54. Veron G, Heard S (2000) Molecular systematics of the Asiatic Viverridae (Carnivora) inferred from mitochondrial cytochrome b sequence analysis. J. Zool. Syst. Evol. Res 38: 209-17.

55. Patou ML, Debruyne R, Jennings AP, Zubaid A, Rovie-Ryan JJ, et al. (2008) Phylogenetic relationships of the Asian palm civets (Hemigalinae \& Paradoxurinae, Viverridae, Carnivora). Mol. Phyl. Evol 47: 883-92.

56. Agnarsson I, Kuntner M, May-Collado, Laura J (2010) Dogs, cats, and kin: A molecular species-level phylogeny of Carnivora. Mol. Phyl. Evol 54: 726-745.

57. Baker CS, Steel D, Choi Y, Lee H, Kim KS, et al. (2010) Genetic evidence of illegal trade in protected whales links Japan with the US and South Korea. Biol. Lett 6: 647-50. 